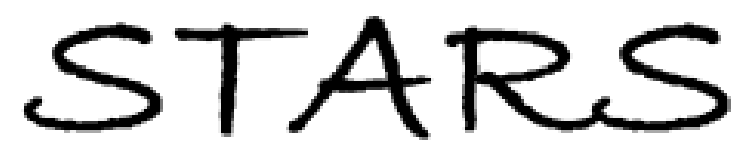

University of Central Florida

STARS

Faculty Bibliography 2000s

Faculty Bibliography

$1-1-2003$

\title{
The presidency and the law: The Clinton legacy
}

Chris J. Dolan

University of Central Florida

Find similar works at: https://stars.library.ucf.edu/facultybib2000

University of Central Florida Libraries http://library.ucf.edu

This Book Review is brought to you for free and open access by the Faculty Bibliography at STARS. It has been accepted for inclusion in Faculty Bibliography 2000s by an authorized administrator of STARS. For more information, please contact STARS@ucf.edu.

\section{Recommended Citation}

Dolan, Chris J., "The presidency and the law: The Clinton legacy" (2003). Faculty Bibliography 2000s.

3707.

https://stars.library.ucf.edu/facultybib2000/3707

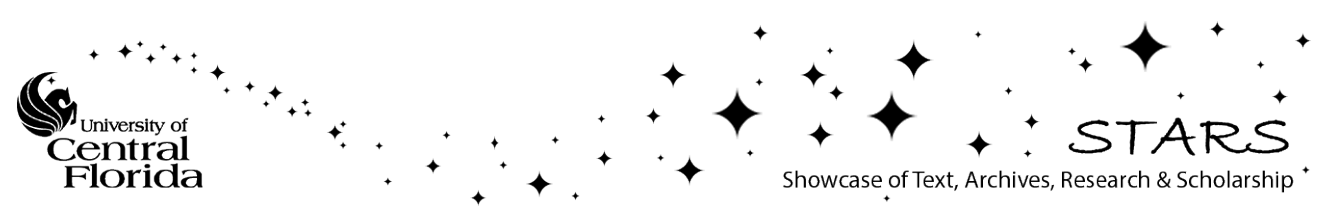


The Presidency and the Law: The Clinton Legacy. Edited by David Gray Adler and Michael A. Genovese. (Lawrence: University Press of Kansas, 2002. Pp. xi, 234. $\$ 40.00$ cloth, $\$ 17.95$ paper.)

Except for a symposium in the September 1999 issue of PS: Political Science and Politics, the constitutional and legal consequences of President Bill Clinton's personal behavior and policies have yet to be thoroughly examined. Filling the void, the edited volume The Presidency and the Law brings together a distinguished group of essayists to provide a measured and historical analysis of the constitutional and legal legacy of the Clinton White House. The research strategy reflects the legalist approach in presidency studies and relies on historical documentation, biographical works, secondary journalistic accounts, and the Public Papers of the President. While there are several drawbacks, the volume represents a contribution to the presidency literature and serves as a reference for wider audiences interested in the constitutional ramifications of this highly controversial president.

On the whole, the essayists succeed in capturing the swinging pendulum of the Clinton presidency and the Republican Congress using the classic "invitation to struggle" metaphor. Thomas Cronin encapsulates the overall theme: "Presidents and Congress regularly try to push each other's constitutional and legal boundaries. Tugs-of-war are nothing new in Washington, DC. Yet Clinton and Congress, as you will read in these chapters, brought these clashes to a new level in several areas" (xii). Mark Rozell's chapter on executive privilege bears this out. Clinton's assertion of executive privilege in the travel office inquiry and in defense of the First Lady regarding her deliberations in the Lewinsky investigation were unprecedented abuses that will forever taint presidential claims of secrecy.

The impeachment drama of 1998 and early 1999 illustrated that both the executive and legislative branches are capable of exercising constitutional brinksmanship. For Robert Spitzer, congressional Republicans took full advantage of the Independent Counsel (IC) statute and used their 1994 legislative victory to exact revenge on Democratic investigations into the Reagan and Bush Administrations. The appointment of Kenneth Starr was a reflection of the intense desire to politicize investigations into Paula Jones's harassment allegations, the Whitewater scandal, the Vince Foster suicide, and the Monica Lewinsky affair. Using Richard Pious's "legal backlash" and "political frontlash" designations, David Gray Adler and Nancy Kassop contend that Clinton's expansive exercise of presidential prerogative diminished the prestige of the Oval Office and usurped the principle of executive independence in Article II. Clearly, the Clinton impeachment transformed constitutional struggles between the presidency and Congress into a nasty form of partisan politics never before seen in American politics.

The implications for presidential power are complicated. Kassop argues that while interbranch conflict intensified during the Clinton years, the Clinton legacy reinforces the model of executive advantage. As evidence, she points to Clinton's decision to order air strikes against Serbia without legislative consent immediately after the Senate impeachment trial. However, Louis Fisher maintains that 
while Clinton was politically successful in escaping removal from office, his "self-inflicted injuries" harmed the legitimacy of the presidential institution. Along these lines, Victoria A. Farrar-Myers argues that the extent of Clinton's exploits as fundraiser-in-chief transformed the Democratic Party into a soft money machine that served the interests of the White House at the expense of the party. For Adler, "President Clinton made no effort to curtail executive aggrandizement of power or to stem the tide of legislative abdication, nor did he seek to restore congressional authority" (177).

While the volume possesses substantive strength, the reader should be mindful of several apparent drawbacks. The focus on constitutional and statutory sources of authority overlooks the importance of political context, a common accusation by critics of the legalist tradition. Nowhere in the analysis is a discussion of how Clinton's self-destructive behavior, use of party resources for self-promotion, and abuse of constitutional authority produced significant political consequences for Democrats in 2000. For example, to what extent did Clinton's actions play a role in Vice-President Al Gore's inability to prevent just enough mavericks in his liberal base from supporting Ralph Nader?

A related example deals with the political ramifications of Clinton's unilateral decision to use force in the former Yugoslavia only two months after his acquittal in the Senate. In contending that such a decision was an exercise in presidential prerogative, the contributors fall short in advancing tentative political answers as to why the Republican Congress failed to oppose the White House. Relevant political factors, such as favorable public approval of the president, a booming economy, international political pressures, and public criticism of House and Senate Republicans are not adequately discussed. In general, the volume does not make an effective distinction between the informal dynamics of executive power, which often produce political opportunities for policy action, and formal authority structures constrained by constitutional and statutory provisions.

In addition to the substantive limitations of the legalist perspective, the volume does not lend itself to theory building, hypothesis testing, or methodological rigor. Making judgments based on interpretations of legal authority and constitutional structures may stimulate lively debates, but do not produce data necessary to arrive at empirical generalizations or to enhance theoretical significance. While such limitations are not unique to legalists, the problem is that the volume's contributors do not put forth political or scientific interpretations of Clinton's legal legacy. As a result, the contributors confirm the obvious, that the Clinton White House, like others before it, interpreted legal provisions in order to concentrate authority in the executive branch at the expense of Congress.

The Presidency and the Law challenges presidency scholars to raise important normative questions of accountability, responsiveness, and responsibility regarding the constitutional parameters of presidential power. Despite its limitations, scholars should welcome it as a contribution to the literature on the constitutional implications of the Clinton presidency. 